\title{
INTERPRETATION OF VERSES ON CONSUMPTION (Application of Quranic Economic Tafsir)
}

\author{
By: Lukman Fauroni ${ }^{1}$
}

\begin{abstract}
This essay tries to develop economic studies from the point of view of Quranic economic tafsir. As a methodology, tafsir plays significant role in order to develop Islamic economic discipline. This model of economic tafsir derived from the thematic Quranic interpretation is developed through four phases including; classification of Quranic verses pertinent to economic affairs, understanding them based on chronology, micro and macro context, and socio-economic contextualization. To sum up, this paper reveals that the consumption behavior in the Quran is ruled harmoniously, gradually and systematically in order to propose the new model of consumption for the Muslim community through eight axiomatic Islamic consumption behavior.
\end{abstract}

Ò)̛̣̣̂̂n

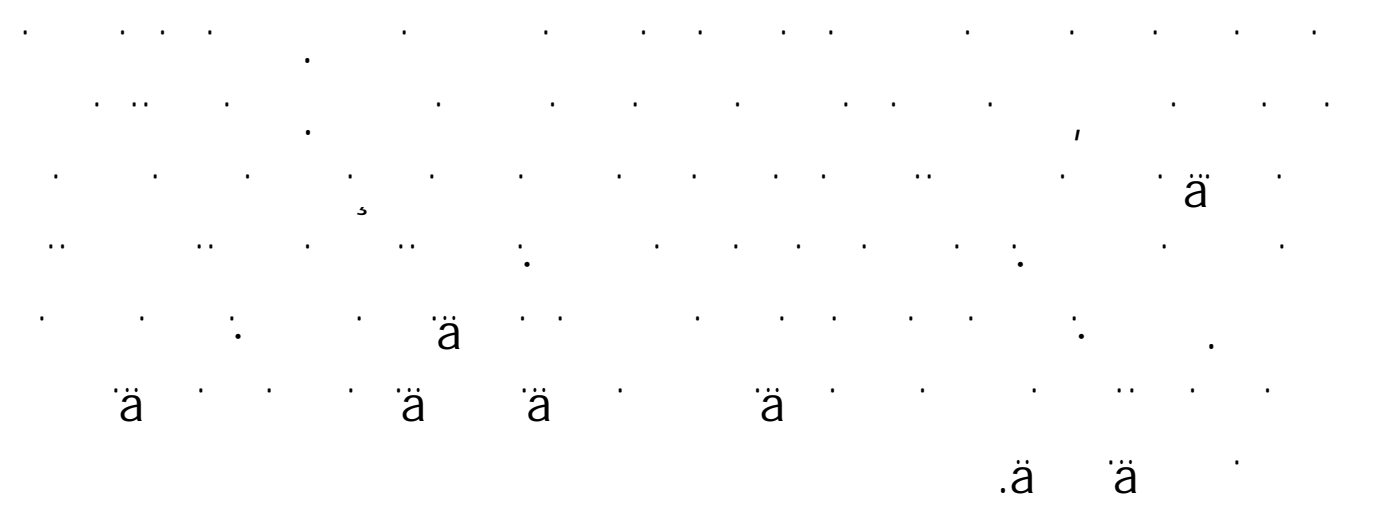

Keyword: economic tafsir of al-Qur'an, adabi al-Ijtima'i wal iqtishadiyyah, consumer behaviour, axiomatic Islamic consumption behavior

\section{A. Introduction}

Al-Qur'an is a source for scrutinizing and developing Islamic teaching in various dimensions of human life. To scrutinize and develop Al-Qur'an

\footnotetext{
${ }^{1}$ A lecturer of STEI Yogyakarta, the participant of Islamic economic doctoral program, UIN Sunan Kalijaga. Email: elfauroni@ yahoo.co.id.
} 
comprehension, it is required a qualification of particular ability to produce a good understanding in regards to all sorts of behaviour of human life including economic aspects.

Consumption behaviour in Islamic economic study has a different typical characteristic of behaviour standard. Ideally each Moslem's behaviour including consumption behaviour shall have a reference from Al-Qur'an and Hadits. Therefore the development of Islamic economic discipline shall be scrutinized and developed from those both sources.

Basically the development of Qur'anic economic study has an equal opportunity with the development of other field of studies within the tradition of Islamic science. Unfortunately, as a branch of science, Quranic economic study is not rapidly developed yet. Though, the necessity towards this science is considered very urgent due to the failure of modern economic science

The treasury of muamalah fiqh has a significant contribution to its field but since it is born and grown within the field of Islamic Law (Fiqh), muamalah figh ${ }^{2}$ seems to be apart from economic science. Due to that, the scrutiny of Islamic economic discipline that is developed from the source of Al-Qur'an without leaving the treasury of study i.e. muamalat figh will be a duty of Islamic Economist.

This article will interpret any verses concerning consumption with Qur'anic economic tafsir approach. The choice on consumption issue is based on the necessity of a good consumption behavior. Consumption belongs to a problematic issue but it is very strategic in determining economic balance. If a community's consumption is high, it may raise economic problems such as inflation, price instability, hoarding practice, food stuff scarcity and unstableness of market. Annual economic problems

${ }^{2}$ In the context of Islamic economic discipline expansion, according to Munrokhim Misanan muamalat figh is considered as the first generation. Second generation, normative Islamic economy is the combination between Islamic teaching and muamalat fiqh. The third generation is the implementation of Islamic economy in economic practice that is seen by the growth of syariah financial institutions. And the fourth generation is formulation of Islamic Economic discipline theory. This categorization in one side namely reality aspect is true but having no concrete fundamental histories data. 
such as high inflation rate on each fasting month, Idul Fitry day and moreover when close to Christmas and New Year celebration, one of them is caused by the high consumption style of community.

\section{B. Methodology}

As a methodology, Qur'anic economic tafsir plays a significant role to develop Islamic economic discipline. The model of economic tafsir derived from the thematic tafsir method that is developed through the following phases: First, inventing any verses dealing with economic issue to be analyzed either based on the key notes or the contents of verses. Second, classifying the verses based on the chronology of their revelation period which is supported by asbabun nuzul both micro and macro. Third, interpreting the verses with adabi al-ijtimâ'i waliqtishâdiyyah approach. ${ }^{3}$ Fourth, conducting socio-economic contextualization ${ }^{3}$

\section{Consumption}

Consumption is derived from Dutch word, consumptie, meaning an activity aimed at reducing or spending the useful power of material, goods or service in order to fulfill the needs/necessity. Consumer is an individual or a user group of goods or service. If the purchasing is aimed for being sold, it is called a distributor.

Income degree sufficiently determines the consumption style. High income enables the high consumption. However, the correlation between income and consumption is not always similar for all goods and services. ${ }^{4}$ Consumption can be varied as per income condition. Income variation on the consumer commonly causes the alteration on the number of requested goods, particularly on the normal or

\footnotetext{
${ }^{3}$ Choosing method base of adabi al-ijtimâ' $i$ which is elaborated to an economic axis is based on a conclusion that the economic axis is a social field. Basically, it can be directly conducted through adabi al-iqtishâdiyah method. However, for the last method, based on my knowledge, there is no any exegesis book which includes in this category. Therefore, the adabi al-ijtimâ' $i$ wal iqtishâdiyah method stands on exegesis which are grouped to adabi al-ijtima' $i$ characterized exegesis.

${ }^{4}$ Lincolin Arsyad, Ekonomi Manajerial, Ekonomi Mikro Terapan untuk Manajemen Bisnis, (Yogyakarta: BPFE, 1998), p. 85.
} 
superior goods. On the contrary the decreasing of consumer's income causes the decreasing of those both goods consumption.

The change of requested goods quantity is influenced by two factors. They are substitution effect and income effect. Substitution effect is a substitution of requested goods when price substitution is happening, while the income is adjusted in order that the consumer satisfaction is constant. Substitution effect has a negative value because the price substitution and quantity are always contradictory. When the price of goods is high, the consumption will be decrease. In contrast, when the price is low, the consumption will be increase. ${ }^{5}$

On the other hand, the quantity of consumed goods may be changed when real income substitution occurs though the price is stagnant. Real income substitution is always contradictory with price substitution. The increasing of price will decrease the real income; the decreasing of price will increase the real income. The income effect may cause positive or negative effect.

A consumer is commonly faced to a number of goods that should be chosen for being consumed. S/he should choose because the income or earning owned is limited to get the spread goods and service. In consumption theory, it is learned how a consumer make a decision to choose the goods and service along with their quantity to be consumed.

According to Umar Burhan, the useful power of goods is which that can give satisfaction called utility. Certainly the utility of one goods is not always similar to others. The utility may be varied due to the difference of time or place.

Of the explanation above, it can be concluded that a consumer shall choose more useful goods for himself, useful goods with more profitable utility and give a satisfaction. A good utility is a utility that gives satisfaction and benefit. p. 66.

\footnotetext{
${ }^{5}$ Umar Burhan, Konsep Dasar Teori Ekonomi Mikro, (Surabaya: BPFE UNIBRAW, 2006),
} 
How Islamic economy views the consumer's behaviour? There are four principles in Islamic economic system especially in economic behaviour including consumption:

1. Abstain from wasteful and luxurious living; that the economic activity is aimed to fulfill the needs and not satisfying the wants.

2. The implementation of zakat that is compulsory and infaq, shadaqah, wakaf, hadiah/gift donated voluntarily have an effect toward the behaviour of Moslem consumer.

3. Conduct permissible enterprise (permissible conduct) afar from riba/usury, maisir and gharar that consist of raw material, production process, and production output until the distribution and consumption process shall be in permissible frame.

Of those principles, it seems that Moslem behavior model in facing goods and services are not a purpose. All of them are a medium for accumulating the goodness and reward for achieving falah (happiness in the world and the hereafter). Wealth is the core of life therefore it shall be kept and developed through productive systems (An-Nisa: 5). Wealth is a gift of Allah given to human being in accordance with their effort (An-Nisa: 32)

Islam views that everything in the earth belongs to Allah that is created for human being. Human being may own it perfectly but it shall be always under the control of Allah. Therefore the ownership by human being over the goods is a mandate. By those mandate value, human being is demanded to obtain the goods with a good manner.

In contrast, within the conventional perspective, wealth is an asset that belongs to a personal property. As long as the ownership of wealth does not break the rule and law, the wealth will be fully owned by the owner. Thereby the difference between Islam and conventional perspective concerning the wealth is lying on the point of view. Islam tends to view the wealth based on flow concept while the conventional system views based on stock concept. 
Adiwarman discusses about wealth/property which is entered into money and capital discussion. According to him money in Islam is public goods with flow concept characteristics while capital is private goods with stock concept characteristics. While according to conventional perspective, money and capital belong to private goods. ${ }^{6}$

However in practical level, economic behavior is determined by the iman/faith level of individual or a group of people who tend to make consumption behaviour and production in market. Thereby it can be concluded that there are three characteristics of economic behaviour using the faith level as assumption.

1. When the faith is in good/high level, consumption or production motive will be dominated by those three primary motives; mashlahah/public interest, needs and obligation.

2. When the faith is in unfavorable/medium level, the motive is not only dominated by those three motives but also it is significantly influenced by ego, rationalism (materialism) and individualistic wants.

3. When the faith is in bad/low level, economic motive certainly will be dominated by individualistic (selfishness); ego, wants and rationalism.

Correspondingly in consumption, Islam places this one as a part of economic activity that aims to accumulate the rewards to achieve falah (happiness in the world and the hereafter). Basically the consumption motive in Islam is mashlahah (public interest or general human good $)^{7}$ upon the needs and obligation.

\footnotetext{
${ }^{6}$ See Adiwarman Azwar Karim, Ekonomi Islam: Suatu Kajian Ekonomi Makro, (Jakarta: The International Institute of Islamic Thought Indonesia Indonesia, 2002), p. 19-22.

${ }^{7}$ Etymologically, mashlahah means utility or welfare, which by Abu Hamid Al Ghazali (505 $\mathrm{H} / 1111 \mathrm{M}$ ) and Abu Ishaq Al Shatibi $(790 \mathrm{H} / 1388 \mathrm{M})$ the masalih (plural of Mashlahah) is divided into three: essential/daruriyah, complementary/hâjiyah, and desirableltahsiniyah. It is the state's responsibility to make sure that the essential maslahah of a society is well fulfilled. See Muhammad Akram Khan, (1997) "The Role of Government in the Economy", in The American Journal of Islamic Social Sciences, Vol. 14, No. 2, p. 157.
} 
Meanwhile, Yusuf Qardhawi ${ }^{8}$ mentions some moral variables in consumption, some of them are consumption upon the reason and permissible (halal) goods, economization, avoid the luxurious/extravagant life, avoid any debt and avoid the stingy and ungenerous manner. Thereby the consumption activity is one of economic activities of human being that aims to upgrade the religious duty and faith to Allah SWT in order to achieve a glory, peaceful and the hereafter prosperity (falah) by spending money or income either for his/her necessity or charity for others. While in conventional perspective, consumption activity has a close relationship with the maximization of satisfaction (utility).

Sir John R. Hicks ${ }^{9}$ explains about consumption using satisfaction parameter through satisfaction concept (utility) shown within indifferent curve (equal satisfaction level). Hicks elaborates that individual tries to fulfill his/her life needs/necessity through consumption activity on maximum satisfaction level using his/her income level (income as a budget constraint).

\section{Consumption verses}

In Al-Quran, the teaching related to consumption can be derived from the words kulu and isyrabu mentioned 21 times. While eat and drink (kulu wasyrabu) around six times. A number of verses regarding to consumption teaching excluding derivation from the words akala and syaraba besides fi'il amar above for 27 times mentioned. $^{10}$

In Al-Quran, among the verses containing consumption teaching based on the key word and content of consumption meaning are as follows: (a) Al-Baqarah verse 57, 58, 60-61, 168, 172-174, 188; (b) An-Nisa verse 6, 10, 29; (c) Al-Maidah verse 6, 10, 29; (d) Al-An'am verse 118-121,141-142; (e) Al-A'raf verse 31-32; (f) AtPress, 1995).

${ }^{8}$ Yusuf Qardhawi, Peran Nilai dan Moral dalam Perekonomian Islam, (Jakarta: Rabbani

${ }^{9}$ See Sadono Sukirno, Pengantar Teori Mikroekonomi, (Jakarta: Rajawali Press Jakarta, 2002). al-hadis, 1988)

${ }^{10}$ See Muhammad Fu'ad Abdul Baqi, Mu'jam Mufahras li alfadzal-Qur'an, (Qahirah: Dar 
Taubah verse 34; (g) Yusuf verse 47-48; (h) Hijr verse 3; (i) An-Nahl verse 114, 115; (j) Al-Isra verse 26-29; (k) Toha verse 81; (l) Al-Mu'minun verse 51; (m) Al-Furqan verse 31-32; (n) As-Syuara verse 79; (o) Al-Mulk verse 15; (p) Al-Mursalat verse 46. Besides those verses, there many other verses relating to consumption in Al-Qur'an that can be derived from the words syaraba, akhada and others. Regarding to the limitedness of time, merely those verses will be focused in this article.

As elaborated above regarding to the phase of interpretation/tafsir method, those verses are classified into Makkiyah and Madaniyah chapters.

Table 1

Meccan and Medinan Classification

\begin{tabular}{|c|l|l|l|}
\hline No & \multicolumn{1}{|c|}{$\begin{array}{c}\text { Surat Makkiyyah } \\
\text { dan ayatnya }\end{array}$} & No & \multicolumn{1}{|c|}{ Surat Madaniyah dan ayatnya } \\
\hline 1 & Yusuf: 47-48 & 1 & $\begin{array}{l}\text { al-Baqarah: 57, 58, 60-61, 168, } \\
\text { 172-173, 188 }\end{array}$ \\
\hline 2 & Hijr: 3 & 2 & al-Nisa: 6, 10, 29 \\
\hline 3 & al-Nahl: 114,115 & 3 & al-Maidah: 3, 88, 96 \\
\hline 4 & al-Isra: 17, 26-29 & 4 & at-Taubah: 34 \\
\hline 5 & Toha: 81 & & \\
\hline 6 & al-Mukminun: 51 & & \\
\hline 7 & al-Furqan: $7-8,20,67$ & & \\
\hline 8 & as-Syuara: 79 & & \\
\hline 9 & al-Mulk: 15 & & \\
\hline 10 & al-Mursalat: 43,46 & & \\
\hline
\end{tabular}

Of this classification, it is shown that the consumption verses were more revealed in Meccan period or before hijra of the Prophet around 22 verses within 10 chapters. Meanwhile in Medina there were 16 verses within 4 chapters. It indicates that Al-Quran has a great attention regarding to consumption along with the phase of fundamental Islamic teaching implementation. With a number of Al-Quran verses regarding to consumption, it has an implication that the foundations of Islamic economic teaching were established at the beginning of Islam period.

When the verses and chapters are sorted based on the chronology of Al-Quran revelation, then they can be classified into Meccan and Medinan clusters. This 
classification is aimed to observe the phases of Al-Quran teaching application related to consumption. Logically the verses that were revealed in advance will be a fundamental procedure while other verses revealed later on are further elaboration and commonly being an operational procedure. Data of the revelation sequence of AlQuran chapters are based on the data of mushaf Rabithah al alam al-Islami, alQur'an al-Karim and Abu Abdillah al-Zanzani, Tarikh al-Qur'an. ${ }^{11}$ Of those sequences, the chronologies of verses containing consumption teaching are as follows:

Table 2

Chronology of Consumption Verses

\begin{tabular}{|c|l|c|l|}
\hline $\begin{array}{c}\text { No } \\
\text { urut }\end{array}$ & \multicolumn{1}{|c|}{ Makkiyyah } & $\begin{array}{c}\text { No } \\
\text { urut }\end{array}$ & \multicolumn{1}{|c|}{ Madaniyyah } \\
\hline 33 & al-Mursalat: 43, 46 & 87 & $\begin{array}{l}\text { al-Baqarah: 57, 58, 60- } \\
61,168,172-173,188\end{array}$ \\
\hline 39 & al-A'raf: $31-32$ & 92 & al-Nisa: 6,10, 29 \\
\hline 42 & al-Furqan: 7-8, 20, 67 & 112 & al-Maidah: 3, 88, 96 \\
\hline 45 & Toha: 81 & 113 & at-Taubah: 34 \\
\hline 47 & as-Syuara: 79 & & \\
\hline 50 & al-Isra: $16,26-29$ & & \\
\hline 53 & Yusuf: $47-48$ & & \\
\hline 54 & Hijr: 3 & & \\
\hline 55 & $\begin{array}{l}\text { al-An'an: } 118-121,141- \\
142\end{array}$ & & \\
\hline 70 & al-Nahl: $69,114,115$ & & \\
\hline 74 & al-Mu'minun: 51 & & \\
\hline 77 & al-Mulk: 15 & & \\
\hline
\end{tabular}

\section{E. Principles of Consumption in Al-Quran}

Further step of this Quranic economic tafsir methodology is interpreting those verses with adabi al-ijtimâ'i wal iqtishâdiyah approach. This phase is aimed at achieving the principles of consumption.

${ }^{11}$ Quoted from the book appendix of Abd Muin Salim, Konsepsi Kekuasaan Politik dalam al-Qur'an, (Jakarta: LSIK, 1994), pp. 329-330 
In verse 43 of Al-Mursalat, Allah has instructed to eat and drink easily in consequence of human being efforts. This verse is correlated with the previous verse (verse 41) that describes the reward for sacred men that is a shaded shelter around a spring. Possibly it describes a life in heaven or a prosperous and happy life in the world as a reward from Allah to the sacred men.

In contrast, in verse 46, Allah has warned the unbelievers who deny the truth that the world life and all its pleasure is temporary. Although they could eat and drink easily but the destiny of the unbelievers keep on the bad luck. The pleasure and enjoyment of all being consumed in the world are temporary.

In the next phase, in al-A'raf: 31-32 regarding consumption, Allah has warned the mankind to proportionally wear anything that could be worn such as clothes and others and not excessive.

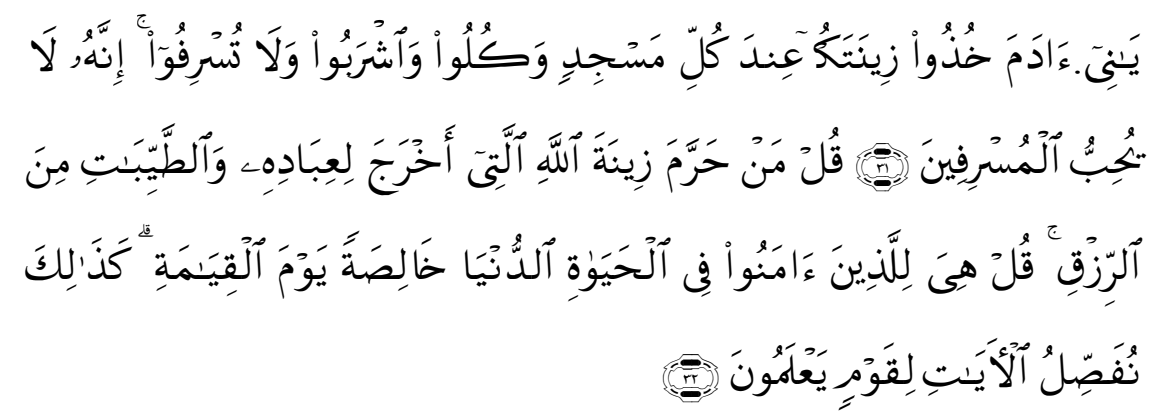

31. O Children of Adam, wear your beautiful apparel at every time and place of prayer: eat and drink: but was not be excess, for Allah loveth not the wasters.

32. Say: who hath forbidden the beautiful (gift) of Allah, which he hath produced for his servants, and the things, clean and pure, (which He hath provided) for sustenance? Say they are, in the life of this world, for those who believe, (and) purely for them on the Day of Judgment thus do we explain the Sign in detail for those who understand.

This verse is revealed due to a phenomenon experienced by some Prophet's companions who pretended al-Hummas group, an orthodox Quraisy who did not want to perform thawaf unless otherwise wearing a new clothes that never been worn for a 
bad deed and also very selective in choosing food and its amount while performing hajj. That verse is a warning of Allah upon excessive behaviour of mankind in performing a religious service in regards to the clothes use.

According to Quraisy Shihab, the verse 31 contains a meaning about the compulsion of wearing a fine-looking and proper clothes and covering up aurat as well. The use of clothes anytime entering or while inside the mosque, both in particular meaning and the mosque in general meaning that is earth of Allah. Eat permissible, delicious, beneficial and nutritious food and having a good effect for physic. Drink any beverage you prefer as long as not intoxicated and disturb the health. Do not be excessive/ extravagant because Allah hates extravagant people, not bestowing any mercy and reward to extravagant one. ${ }^{12}$ Thereby, of the above verse it can be gotten a consumption principle that is proportional and not excessive or not obeying the desire.

Not excessive within a goodness and proportional in consumption is yet mentioned when Allah describes the Prophet Mohammad's character as a messenger who also has the human character, eat and drink and conduct economic activity in market as well. Prophet Mohammad is not an angel who does not eat and drink. That is the content of Al-Furqan: 7-8, 20.

Meanwhile in Al-Furqan verse 67 Allah describes that good consumption behavior is not excessive in spending wealth and also not stingy/ungenerous but in the middle of them. The middle here can be meant harmonious and proportional, in other words expenditure shall not be higher than revenue (a frog dreams to be a buffalo (proverb))

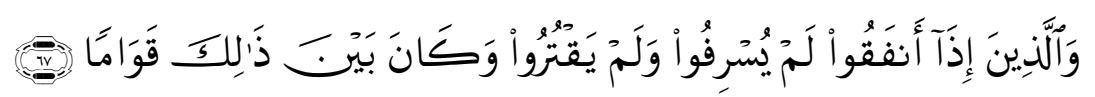

67. Those who, when they spend, are not extravagant and not niggardly, but hold a just (balance) between those (extremes).

\footnotetext{
${ }^{12}$ M. Quraisy Shihab, Tafsir Al-Misbah Pesan, Kesan dan Keserasian al-Qur'an, volume 5, (Jakarta: Lentera Hati, 2003), pp. 75-76
} 
Thereby verse 67 declares consumption principle that is balance/harmonious, expenditure is not higher than revenue. It is also emphasized in another verse (Toha: 81) which says "Eat of the good things we have provided for you sustenance, but Commit no excess therein, Lesy My Warth should justly descend on you”. Here is the consumption principle of gratefully accepting Allah's gifts shown. Because in truth, It is He Who gives food and drink (QS. as-Syuara: 79)

Then it is strengthened by QS al-Isra': 26-29.

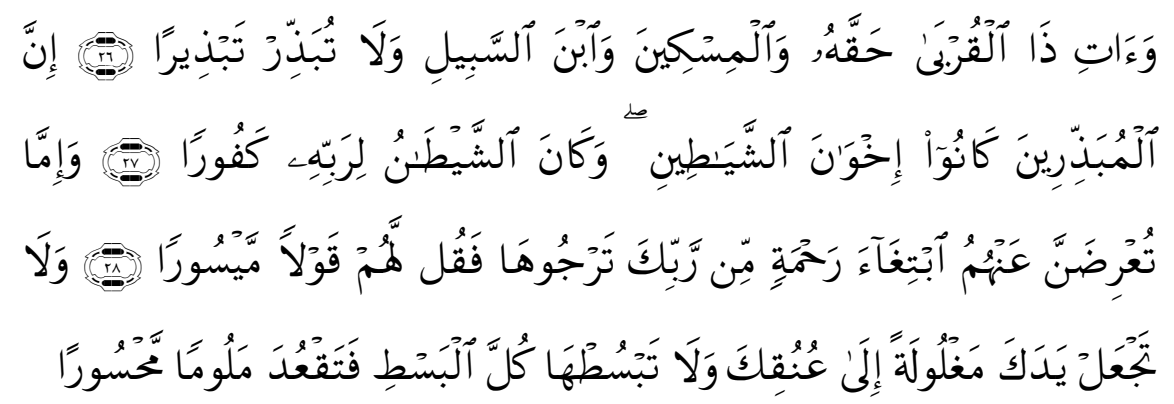

26. And render to the kindred their due rights, as (also) to those in want, and to the wayfarer: but squander not (your wealth) in the manner of a spendthrift. 27. Verily spendthrifts are brothers of the evil ones; and the evil one is to his Lord (himself) ungrateful.

28. And even if thou hast to turn away from them pursuit of the mercy fro thy Lord which thou dost expect, yet speak to them a word of easy kindness.

29. Make not thy hand tied (like a niggard's) to thy neck, nor stretch it forth to its utmost reach, so that thou become blameworthy and destitute.

All four verses above give an explanation pertinent to consumption in some cases. First, it is a goodness to give basic necessities of life that is the fulfillment of basic needs to family, relatives, poor person and ibn sabil. Second, avoid extravagant behaviour because extravagant is Satan behaviour. Third, avoid stingy/ungenerous behavior and also not excessive in giving alms/charity. Thereby, of all four verses above it can be got the consumption principles that support the fulfillment of basic need of family, relatives, poor men and ibn sabil, avoid extravagant and stingy behavior but due to ability. 
In Yusuf: 47-48, based on the story of the Prophet Yusuf regarding to his consumption way, we can get an economical consumption principle, considering the future necessity. It was reflected on the economic policy of the Prophet Yusuf who planting the wheat as usual then stored it with its stem and seed and consumed it economically in order to be able to prepare the necessity in a difficult future. Thus, if a community has a consumption behaviour that follows the pleasure and desire, they will be relaxed by a vacant dream/obsession that may cause a disadvantage in the future. Thus the content of the Quran, Al-Hijr: 3

Therefore in consumption process and operational shall comply with the established rule and law. Among the rule of Quranic consumption, they are in AlAn'am: 118-121 and 140-141, some of them are eating a livestock that is slaughtered in the name of Allah, not consuming any illegal (haram) thing, not obeying the desire in consumption, spending farming and livestock zakat in the harvest time and not following the Satan way because Satan is the real enemy for human being. Thereby, of those verses above it can be taken a principle to comply with the principle of law in consumption.

After Al-Quran teaches about consumption through the nine sequences of verses above, then Allah yet explain about consumption teaching in An-Nahl: 114115. In these verses the word halal is then mentioned and connected with the word thayyib. If correlated with the chronology of an-Nahl revelation that was revealed on the $70^{\text {th }}$ episode in the Mecca period, it can be concluded that the application of halal/permissible term was recently executed in the last period of Mecca.

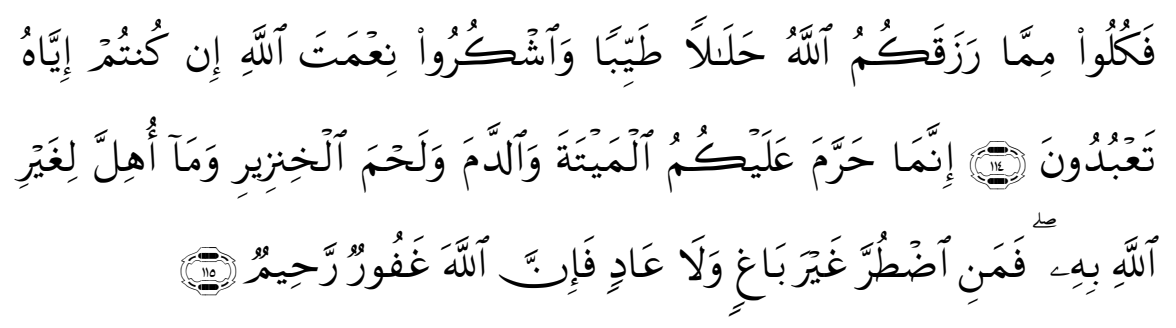


114. So eat of the sustenance which Allah has provided for you, lawful and good; and be grateful for the favour of Allah, if it is He Whom ye serve.

115. He has only forbidden you dead meat, and blood, and the flesh of swine, and any (food) over which the name of other than Allah has been invoked. But if one is forced by necessity, without willful disobedience, nor transgressing due limits, than Allah is Oft-Forgiving, Most Merciful.

In the verses above, Allah require halal/permissible and good quality for anything that may be consumed and command the mankind in order to thank upon Allah's mercy along with the assumption if Allah the one to be served. Thereby in sura An-Nahl verse 114-115 there are halal/permissible and good quality consumption and also thankful principles. The instruction of consumption is not only aimed to the common people but also to all messengers. It is reflected in AlMukminun: 51 "O ye messengers! Enjoy (all) things good and pure, and work righteousness: for I am well-acquainted with (all) that ye do”.

In the last verse of Mecca chapters concerning consumption that is Al-Mulk: 15, Allah state that It is He Who has made the earth manageable for you, so traverse ye through its tracts and enjoy of the Sustenance which He furnished: but unto Him is the Resurrection. In consumption context, the certainty that all human beings will return to Allah might be taken a principle of responsibility that anything we consume will have an impact to human body and their behaviour.

Based on the above elaboration, it can be resumed that the consumption principles that were revealed in the Mecca period tend to be fundamental teachings that consists of eating and drink easily from the result of an effort or enterprise and a warning that the pleasure and joyful are temporary (Al-Mursalat: 43 and 46), a direction to execute consumption proportionally and not excessive or not obeying the desire (Al-A'raf: 31-32). Consumption behaviour shall be balance/harmonious, expenditure shall not be higher than revenue (Al-Furqan: 67) receive the gift with thankful behaviour and execute a good consumption of Allah mercy moderately (Toha: 81) It is He Who gives food and drink (As-Syuara: 79). 
Furthermore, remember that the consumption is not only done to fulfill individual needs but also the basic needs of family, relatives, poor men and ibn sabil and not with extravagant and stingy manner but as per ability (Al-Isra': 26-29). Therefore the consumption shall be done economically. It is based on the story of the Prophet Yusuf (Yusuf: 47-48).

In contrast, if not efficient in consumption but following the joyful and desire, they will be relaxed by the dream that may cause a disadvantage in the future (AlHijr: 3). Therefore in its operational process, the consumption behaviour shall comply with principle of law, for instance only consume a livestock that is slaughtered in the name of Allah, not consuming any prohibited (haram) substance, not obeying the desire and spending zakat in harvest time and also not following the satanic way.

Obeying the principle is not only in formal way in term of legalization of its dzatiah/substance but it contains a philosophical principle, for that reason in AnNahl: 114-115, consumption shall be done in permissible/halal and good manner. Halal here means the legalization of its substance/object as anything that is legalized by Al-Quran. Good means the good effect of it. After the establishment of this principle then it is also stated that in consumption there is a responsibility principle that means anything being consumed certainly will have an impact to human physic and his/her behaviour (QS. al-Mulk:15).

What is the content of consumption verses in the Medina sura? As elaborated in the beginning, the consumption verses in the Medina chapters are less than that of the Mecca, which are 16 verses in 4 chapters. What meaning is contained behind the fact?

In Al-Baqarah 57, 58 and 60-61, Al-Quran states the power of Allah who had gave grants in form of al-mann and as-salwa to Hebrews when they were lost between Syam, Syuria, Lebanon and Egypt until they were able to enter the fertilized Baitul Maqdis. Besides the gift of al-mann and as-salwa, in verse 60-61 Allah had granted 12 springs as the miracle of the Prophet Musa that being the springs of life for the Prophet Yakub descent. Unfortunately the followers of Musa were not 
satisfied even though they had been granted a great deal of gifts. They refused the food as if a bird and sweets is like honey; even they asked Allah to change those with vegetables. That is why they got the lowness and sadness because they were greedy in achieving the pleasure of the world. ${ }^{13}$

In the next verse, Al-Baqarah: 68, Allah states to the mankind to consume any permissible and good quality food only and never try to follow the Satan ways.

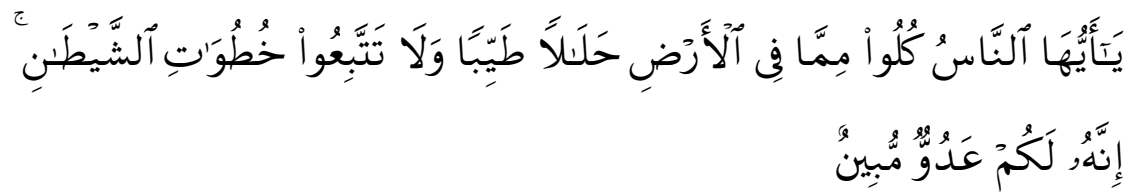

168- O ye people! Eat of what is on earth, lawful and good, and do not follow the footsteps of the Evil One, for he is to you an avowed enemy.

Satan has a way that is able to entrap the humankind, food and beverage can be a medium for Satan to trick human being in order to go into their trap. This statement, basically to remind that long time ago, Adam and Eva were entrapped in the trick and temptation of Satan through the medium of food.

Thereby in verse 168 there is a principle of permissible/halal and fine consumption and the prohibition to follow the satanic way in the meaning of following desire. Taste or desire may change a wants to become a needs. In this context, consumption behaviour shall comply with the degree and standard of needs and not the standard of wants. The mention of permissible/halal and good quality in this verse is a restatement of halal and good quality established in An-Nahl: 114 that was revealed in the last period of Mecca before Prophet Mohammad emigrated to Medina.

In the verse 172-173 Al-Quran specifically persuades believers to only consume the good things from the gift of Allah along with the gratitude to Allah upon the gift given to us. In the next verse, verse 173 Al-Quran elaborated prohibited things to be consumed which covers: dead meat, spilled blood, bacon, animal that is not ritually slaughtered in the name of Allah. In this verse seem that only the

\footnotetext{
${ }^{13}$ M. Quraisy Shihab, ibid, vol 1, pp. 202-204 and 210-212
} 
mentioned things that are prohibited to be consumed though it is not in this way. This context is then elaborated in the Prophet tradition.

It is really interesting, the point of view of Hasan Raid (2001) quoted by Anom Surya Putra, that is called the spilled blood is not only consuming the spilled blood within a literal meaning. Consume the spilled blood can be a human exploitation just like the exploitation of labor by the capitalist in capitalist economic system. $^{14}$

After Al-Quran elaborates halal/permissible and haram/prohibited things, later on Al-Quran explains consumption in the larger scope of individual relationship that is the relationship between business and investment that shall be protected by etiquette principle. Moreover when occur any dispute related to property/wealth, never solve it by manipulating the politics of power as well. It is stated in AlBaqarah: 188:

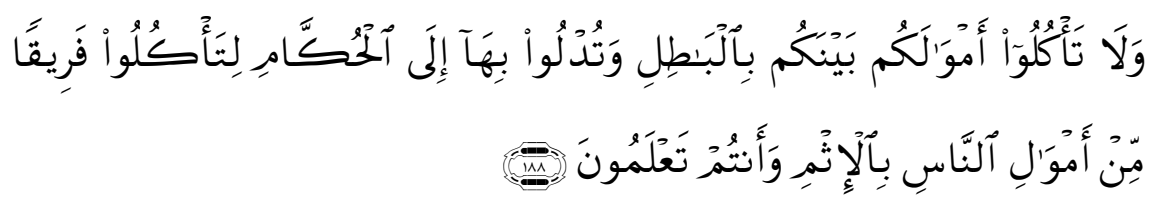

188- And do not eat up your property among your selves for vanities, nor use it as bait for the judges, with intent that ye may eat up wrongfully and knowingly a little of (other) people's property.

Based on the context, this verse demands mutual business partnership. When two parties make the partnership in unbalanced situation, process and result, the partnership can be an iniquity act. The content of this verse is similar to another consumption verse concerning partnership issue i.e. An-Nisa: 29. The purpose of business partnership is achieving an agreed target namely a mutual profit. Prohibition to complain about to a law court by bribing the judge to win the case is extremely

\footnotetext{
${ }^{14}$ The Hasan Raid's view is an interpretation of QS. al-An'an: 145. See Anom Surya Putra, "Man ista'jara ajran fal yu'alimhu ajrahu". www.nu.online.com Accessed in 14 January 2008
} 
prohibited in this verse. Of this verse, it can be taken a consumption principle that is a mutual advantage based on the justice principle.

In the further phase, An-Nisa: 6 and 10 explain the management system of orphan wealth/property. The orphan wealth is frequently mandated to an appointed guardian, either relatives guardian or guardian promoted by a law court. The guardian has to properly manage the orphan wealth and save it from any lost till the orphan reaches the adulthood/baligh. Of his effort, the guardian deserves to get a proper benefit as an ujrah, but surely not excessive.

In verse 10 , it is also stated that:

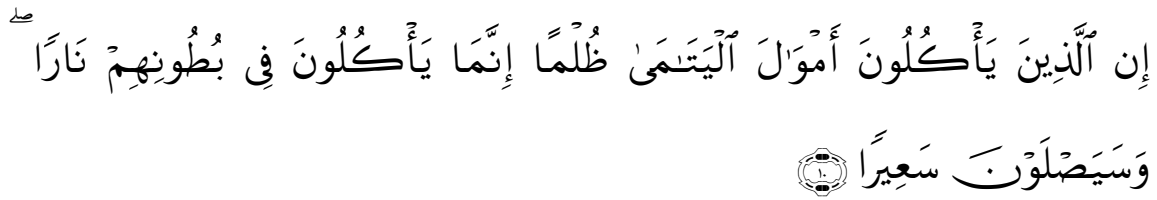

10. Those who unjustly eat up the property of orphans, eat up a fire into their own bodies: they will soon be enduring a blazing fire.

The threat for those who execute the consumption behavior greedily is that they are like consuming fire to their abdomen and they will be entered into the hell which has the hottest burning fire. This threat is extremely strict and serious. Therefore, Al-Quran expects a consumption behavior that is afar from or not containing the greediness. That is a consumption principle from verse 10 of An-Nisa.

If the partnership in managing and developing the wealth in verses 6 and 10 of An-Nisa restricted in the scope of close family, then in verse 29 widely states about the consumption behaviour in managing and developing the wealth in general scope. 


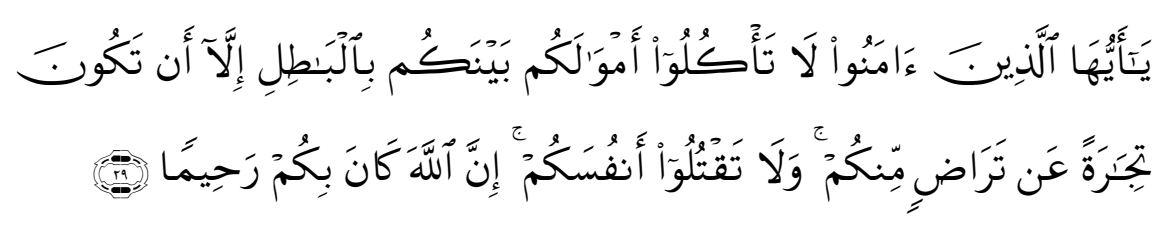

29. O ye who believe eat not up your property among yourselves in vanities: but let there be amongst you traffic and trade by mutual good will: nor kill (or destroy) yourselves: for verily Allah hath been to you Most Merciful.

According to Al-Maraghi this verse is a general norm concerning transaction in term of wealth as an effort for purifying the soul in gathering the beloved wealth. ${ }^{15}$ Collect, use or even consume the wealth is allowable as long as there is no iniquity within the process. The behaviour of taking the wealth without any substitution, without the willingness of owner, or using the wealth in the wrong way is not the consumption behavior expected by this verse. Iniquity is everything that is wrong, unjust, useless, and having no advantage ${ }^{16}$ and or the opponent of truth, everything that contains nothing, no benefit in it although after being investigated. ${ }^{17}$

Obviously, in that verse is stated to not consume other people's wealth with a bad manner. According to Quraish Shihab, eating is a basic need of human being. Whatever business and job is, wealth must be basically utilized and some of them be consumed. If eating as a basic need is prohibited when conducted with a bad manner, certainly it is more prohibited for fulfilling the secondary and tertiary needs. ${ }^{18}$ In this verse, the behaviour that shall be avoided by Moslem consumer is not only in the context of inter individual relationship such as partnership or a joint as in the whole process of manufacturing. This is the meaning of bainakum of that verse. Thereby, of this verse it can be taken a consumption principle that is not containing an iniquity.

${ }^{15}$ See Lukman Fauroni, Etika Bisnis dalam al-Qur'an, (Yogyakarta: Pustaka Pesantren, 2006), pp. 104-105

${ }^{16}$ Ahmad Warson Munawir, (1983), Kamus al-Munawwir, pp. 99-100

${ }^{17}$ See ar-Raghib al-Isfahani, al-Mufradat fi Gharib al-Qur'an, pp. 50-51

${ }^{18}$ Ibid, p. 105 
Furthermore in Al-Maidah: 3, as a small part of the real sample of food containing a bad thing, it is stated any prohibited food to be consumed. If in An-Nahl: 114-115 that were revealed in the last period of Mecca it is mentioned that

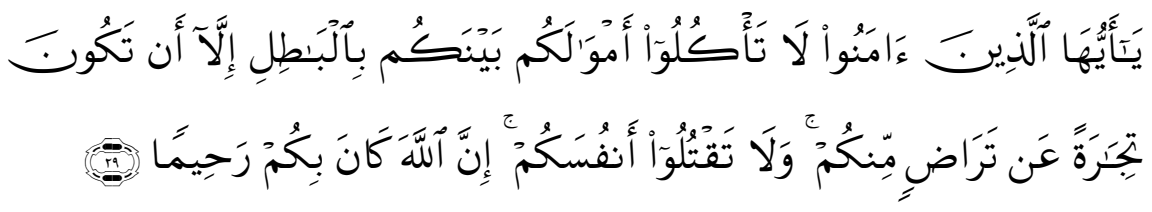

"So eat of the sustenance which Allah has provided for you, lawful and good...... He has only forbidden you dead meat, and blood, and the flesh of swine, and any (food) over which the name of other than Allah has been invoked",

Then in verse 3 of Al-Maidah it is mentioned as the following:

Forbidden to you (your food) are: dead meat, blood, the flesh of swine, and that on wish hath been invoked the name of other than Allah; that which hath been killed by strangling, or by a violent blow, or by a headlong fall, or by being gored to death; than which is sacrificed on stone (altars); (forbidden) also is the division (of meat) by raffling with arrows: that is impiety. This day have those who reject Faith given up all hope of your religion: yet fear them not but fear me. This day have I perfected your religion for you, completed my favour upon you, and have chosen for you Islam as your religion. But if any is forced by hunger, with no inclination transgression, Allah is indeed Oft-Forgiving, Most Merciful.

Thereby, the application of consumption behavior on the community that used to be familiar with the mistake consumption behaviour was conducted gradually. AlMaidah 3 was revealed in Medina, where the Moslem community had been in better advancement and also the community's faith upon the religion teaching was possibly better than Mecca period. Thus, Allah wisely taught His teaching.

A dilemma between obeying Quranic teaching in the case of consumption and the strong custom that are contrasting one another possibly occurred. Therefore Allah 
has restated in verse 88 and 96 of Al-Maidah in order to be consistent in executing permissible and good consumption behavior.

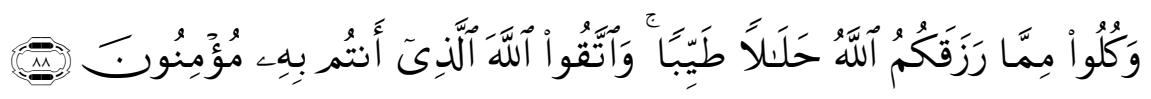

88. Eat of the things which Allah hath provided for you, lawful and good; but fear Allah, in whom ye believe.

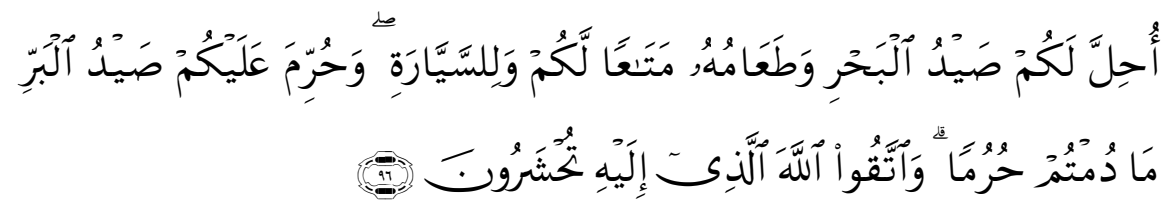

96. Lawful to you is the pursuit of water game and its use for food, for the benefit of yourselves and those who travel; but forbidden is the pursuit of land game; as long as ye are in the sacred precincts or in pilgrim garb. And fear Allah, to whom ye shall be gathered back.

To change the culture is an uneasy matter. Probably in that time some of Moslem Community compared their customs with Hebrew and Christian communities, as the religious communities that were certainly different due to their inconsistence with their original teaching. Therefore Al-Quran strengthens the consistency of Moslem community with At-Taubah: 34.

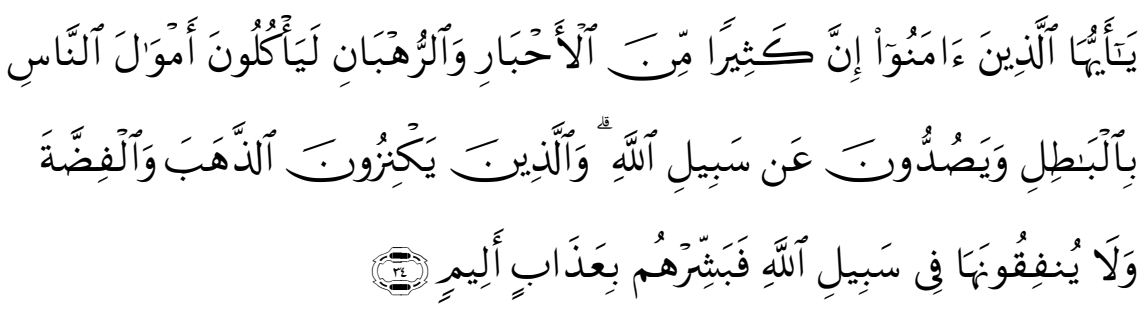

34. O ye who believe there are indeed many among the priests and anchorites, who in falsehood devour the substance of men and hinder (them) from the way of Allah. And there are those who bury gold and silver and 
spend it not in the way of Allah: announce unto them a most grevious penalty.

This verse describes the bad behavior of Ahbar tribe i.e. scholar of Hebrew and monk of Christian that were materialistic or greedy and love to compile the wealth by taking and using other people wealth in a bad manner such as bribing/collusion, manipulating the religious teaching to get material profit. Physically they appear as a religious men who close to God but contrast in the reality. ${ }^{19}$ Thereby, the consumption principle of this verse is that the behaviour of Moslem consumers shall be afar from materialistic, greedy, favor to pile up the wealth, take other people wealth in a bad manner until manipulating the religion teaching in favour of wealth.

\section{F. Conclusion}

Relied on the above elaboration, it is proven that the application of Islamic teaching concerning consumption through Quranic verses was harmoniously, gradually and systematically done to build a community with a Quranic consumption tradition.

In the Mecca period, it was mentioned that a fundamental consumption principle includes eating and drinking the result of work or business and warning that the pleasure and joyful in the world is temporary (al-Mursalat (77) 43 and 46), a guide to execute the consumption proportionally and not excessive or not following the desire (Al-A'raf: 31-32). Consumption behaviour shall be harmonious; expenditure shall not be higher than revenue (Al-Furqan: 67) that is accepting the gift of Allah with a gratitude and execute a good consumption and not excessive (Toha: 81) and in truth, It is He Who gives food and drink. (As-Syuara: 79).

Consumption does not only mean fulfilling personal/individual needs but also the basic needs of family, relatives, poor men and ibn sabil and also avoiding the

\footnotetext{
${ }^{19}$ M. Quraish Shihab, ibid, vol. 5, p. 583
} 
extravagant and stingy manner. Consumption should be considered as per ability (AlIsra': 26-29). Therefore consumption shall be conducted economically (Yusuf: 4748).

The inefficiency of consumption or meeting pleasures, desires and dreams may cause disadvantages in the future (Al-Hijr: 3). Therefore, the operational process of consumption behaviour shall comply with the principle of law and not going with the satanic way by consuming permissible/halal and good quality food only (AnNahl: 114-115). In consumption, there is a responsibility principle that everything consumed will impact human physic and their behavior (QS. al-Mulk: 15).

Furthermore in the Medina period, these principles were strengthened with the statement that "He have bestowed the gift through a very potential nature so the food scarcity can be solved" (Al-Baqarah: 57, 58 and 60-61). Therefore the mankind shall consume permissible/halal and good quality food and should not follow the desire (satanic ways) unless otherwise as per necessity (Al-Baqarah: 168). The characteristic of a believer (mukmin) is always conducting a good consumption of the gift of Allah along with the gratitude to Allah upon His blessing (QS. al-Baqarah: 172-173).

Complain about to the law court to win a case by bribing the judge is extremely prohibited. Therefore, a partnership for consumption shall be based on justice principle namely mutual advantage (Al-Baqarah: 188). Partnership behaviour shall also be separated from or containing a brutality (An-Nisa, 4:10).

Moreover, in consuming and developing the wealth, it shall not contain iniquity manner but it shall be in mutual advantage (An-Nisa: 29). Among the food samples containing the prohibited substances are everything that is prohibited by Allah (Al-Maidah: 3).

To realize a good consumption behavior, Moslem community has to have commitment and be consistent in it (Al-Maidah: 88) and not to pretend other community's customs. The behaviour of Moslem consumers shall be far from materialistic, greedy, love to pile up the wealth, take other people wealth in a bad manner until manipulating the religious teaching in favour of wealth. 


\section{BIBLIOGRAPHY}

Al-Banna, Hasan. 1997. Risalah Pergerakan Ikhwanul Muslimin. Jakarta: Intermedia.

Anom Surya Putra. 'Man ista'jara ajran fal yu'alimhu ajrahu. On www.nu.online. accessed on 14 January 2008.

Baqi, Muhammad Fu'ad Abdul. 1988. Mu'jam al-Mufahrasy lialfadzi Qur'an. Qahirah: Dar al-hadis.

Karim, Adiwarman Azwar. 2002. Ekonomi Islam: Suatu Kajian Ekonomi Makro. Jakarta: The International Institute of Islamic Thought Indonesia (IIIT Indonesia)

Khan, Muhammad Akram. 1997. 'The Role of Government in the Economy," dalam The American Journal of Islamic Social Sciences, Vol. 14, No. 2

Lukman Fauroni. 2006. Etika Bisnis dalam al-Qur'an. Yogyakarta: Pustaka Pesantren.

Munawir, Ahmad Warson. 1883. Kamus al-Munawwir. Yogyakarta: Pondok Pesantren Krapyak.

Qardhawi,Yusuf. 1995. "Peran Nilai dan Moral dalam Perekonomian Islam." Jakarta: Rabbani Press.

Salim, Abd Muin. 1994. Konsepsi Kekuasaan Politk dalam al-Qur'an, Jakarta: LSIK

Shihab, M Quraisy. 2003. Tafsir Al-Misbah Pesan, Kesan dan Keserasian al-Qur'an. Jakarta: Lentera Hati.

Sukirno, Sadono. 1997. Pengantar Teori Mikroekonomi. Jakarta: Rajawali Press Jakarta

Umar Burhan. 2006. Konsep Dasar Teori Ekonomi Mikro. Surabaya: BPFE UNIBRAW. 